\title{
BIOIMPEDANCE ANALYSIS OF BODY COMPOSITION IN THE DIAGNOSIS OF PHYSICAL DEVELOPMENT DISORDERS IN CHILDREN AND ADOLESCENTS
}

\author{
Gavryushin MYu凶, Sazonova OV, Gorbachev DO, Borodina LM, Frolova OV, Tupikova DS, Berezhnova OV, Trubetskaya SR
}

Samara State Medical University, Samara, Russia

\begin{abstract}
Traditionally, anthropometric method is used in clinical practice for the diagnosis of excess body weight. Obesity is the excess development of primarily visceral and subcutaneous adipose tissue, which can be diagnosed by bioimpedance analysis (BIA). The study was aimed to assess the role of BIA of body composition in the diagnosis of the physical development disorders in children and adolescents. Anthropometric assessment and BIA were performed in 431 Samara school students aged 12-16 of the health status groups I and II (230 boys and 201 girls). The results were analyzed with the use of the regional regression scores, BAZ indices, and the body fat percentage values. The results of estimation using the regression scores showed that $22.61 \%$ of boys and $23.43 \%$ of girls were overweight, while more than $2 / 3$ of the sample had a normal pattern of physical development. The BAZ indices revealed a significantly higher proportion of overweight children among boys $(25.7 \%)$, than among girls $(11.5 \%, p<0.01)$. The body fat percentage fluctuations based on the BIA data were found not only in children with disharmonious physical development, but also in $60 \%$ of children with normal body weight. Moreover, the data of BIA confirmed the body weight fluctuations, revealed with the use of the regression scores, in the significantly larger number of cases compared to the low body weight and excess body weight, diagnosed based on the BAZ indices. Accordingly, anthropometric analysis with the use of the regional regression scores may be used at the baseline for the early diagnosis of the nutritional status disorders in children. To confirm overweight and obesity in children, as well as to provide further treatment, the reliable method for estimation of the body fat content is required, which may be the method of BIA.
\end{abstract}

Keywords: hygiene of children and adolescents, physical development, body mass index, regression scales, bioimpedance analysis

Funding: the study was supported by the grant from the President of the Russian Federation (MK-5809.2021.3)

Author contribution: Gavryushin MYu — research initiator, design, data acquisition; Sazonova OV — scientific management; Gorbachev DO, Borodina LM — literature analysis, manuscript writing and editing; Frolova OV, Tupikova DS, Berezhnova OV — data acquisition, processing of the results; Trubetskaya SR — processing of the results, manuscript writing.

Compliance with ethical standards: the study was approved by the Ethics Committee of the Samara State Medical University (protocol № 2 dated February 24 , 2021). The informed consent was obtained from all participants (their legal representatives).

$\triangle$ Correspondence should be addressed: Mikhail Yu. Gavryushin

Chapayevskaya, 89, Samara, 443099, Russia; m.yu.gavryushin@samsmu.ru

Received: 01.12.2021 Accepted: 15.12.2021 Published online: 28.12.2021

DOI: $10.24075 /$ brsmu.2021.062

\section{БИОИМПЕДАНСНЫЙ АНАЛИЗ СОСТАВА ТЕЛА В ДИАГНОСТИКЕ НАРУШЕНИЙ ФИЗИЧЕСКОГО РАЗВИТИЯ ДЕТЕЙ И ПОДРОСТКОВ}

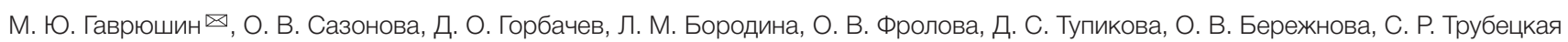

Самарский государственный медицинский университет, Самара, Россия

В клинической практике для диагностики избыточной массы тела и ожирения традиционно используют антропометрический метод. Ожирение - это избыточное развитие прежде всего висцеральной и подкожной жировой ткани, которое может быть диагностировано методом биоимпедансометрии (БИА). Целью исследования было оценить роль биоимпедансного анализа состава тела в диагностике нарушений физического развития детей и подростков. Проведено антропометрическое и биоимпедансометрическое обследование 431 самарского школьника I и II групп здоровья в возрасте 12-16 лет (230 мальчиков и 201 девочка). Анализ результатов проводили по региональным шкалам регрессии, показателю ВАZ и доле жировой массы. Результаты оценки по шкалам регрессии выявили 22,61\% мальчиков и 23,43\% девочек с избыточной массой тела, при этом более 2/3 выборки имели нормальное физическое развитие. Показатель BAZ выявил значимо большее число детей с избыточной массой тела среди мальчиков (25,7\%), чем среди девочек (11,5\%, p < 0,01). Отклонения доли жировой массы по данным БИА определены не только среди детей с дисгармоничным физическим развитием, но и среди 60\% детей с нормальной массой тела. При этом выявленные по шкалам регрессии отклонения массы тела данные БИА подтверждали в большем числе случаев, нежели диагнозы избыточной или недостаточной массы тела, полученные по индексу ВАZ. Исходя из этого, первоначально, для своевременной диагностики нарушений нутритивного статуса у детей, может быть использован антропометрический анализ с применением региональных шкал регрессии. Для подтверждения избыточной массы тела и ожирения у детей, а также для дальнейшей терапии необходим достоверный метод оценки жировой составляющей организма, в качестве которого может выступать метод БИА.

Ключевые слова: гигиена детей и подростков, физическое развитие, индекс массы тела, шкалы регрессии, биоимпедансный анализ

Финансирование: работа выполнена при поддержке гранта Президента РФ (МК-5809.2021.3).

Вклад авторов: М. Ю. Гаврюшин - инициатор исследования, дизайн, сбор материала; О. В. Сазонова — научное руководство; Д. О. Горбачев, Л. М. Бородина - анализ литературы, подготовка и редактирование рукописи; О. В. Фролова, Д. С. Тупикова, О. В. Бережнова - сбор материала, обработка результатов; С. Р. Трубецкая — обработка результатов, подготовка рукописи.

Соблюдение этических стандартов: исследование одобрено этическим комитетом ФГБОУ ВО СамГМУ Минздрава России (протокол № 2 от 24 февраля 2021 г.). Добровольное информированное согласие было получено для каждого участника (его законного представителя).

$\triangle$ Для корреспонденции: Михаил Юрьевич Гаврюшин

ул. Чапаевская, д. 89, г. Самара, 443099, Россия; m.yu.gavryushin@samsmu.ru

Статья получена: 01.12.2021 Статья принята к печати: 15.12.2021 Опубликована онлайн: 28.12.2021

DOI: 10.24075/vrgmu.2021.062 
Physical development is an essential criterion of the comprehensive health assessment, performed during the routine check-ups of children and adolescents, which reflects the impact of the complex set of factors [1-3]. According to the research, carried out in the regions of our country, a little over $60 \%$ of boys and about $67 \%$ of girls are characterized by the harmonious physical development. Disharmonious physical development is due more to the excess body weight, which is found in 18\% of boys and $14 \%$ of girls [3-6]. The importance of the excess body weight issue is defined by high prevalence of pathological conditions and complications, high risk of obesity with comorbidities, resulting in the young patients' disability $[7,8]$. Traditionally, anthropometric method, involving the analysis of the results obtained by the standard measurement of height and body weight, as well as the calculation of the estimation indices, mostly the body mass index (BMI), is used in clinical practice for the diagnosis of excess body weight [9]. The World Health Organization has developed the BMI maps for children and adolescents aged 2-19 to analyze the calculation results [10]. In addition, the weight to height ratio could be assessed using the regression scores, centile charts, and sigma deviations [10].

Obesity is an excess development of the visceral and subcutaneous adipose tissue rather than the total body fat mass [11-13]. Despite the positive correlation between the BMI and the child's anthropometric data, BMI does not reflect the actual body fat percentage, which is continuously changing in children during various age periods. The example of such period is the childhood intensive period of growth, when BMI may indicate the normal weight to height ratio, and the actual fat mass may be underestimated, which could result in the erroneous interpretation of the study results $[8,14]$. In this regard, the use of the anthropometric method only as the diagnostic criterion of overweight and obesity could be questionable. Moreover, low comparability of the research results may be the consequence of the use of different anthropometric diagnostic parameters $[3,6,9,15]$.

In contrast, biophysical methods ensure higher accuracy of the results when measuring the body weight characteristics. Bioimpedance analysis (BIA) of body composition has become the most widely used method. BIA is based on the difference between the resistance (impedance) values of the fat mass and fat-free (lean) body mass, as well as on the total body water and body composition. The assessment results are used in clinical practice to analyze the nutritional status and nutrient intake, the risk of metabolic syndrome, obesity, disorders of cardiovascular system and other systems of the body; the results are also used as the diagnostic criteria for estimation of the therapy efficacy in patients with various diseases [16-19]. For its part, comparison of the results of bioimpedance measurement of the fat mass as a percentage of the body mass and BMI in healthy children shows that a broad range of the body fat percentage values corresponds to the same BMI values [20]. Thus, the use of data, obtained by BIA of body composition, in combination with the anthropometric data as the diagnostic criteria for the abnormal patterns of the children's physical development needs to be studied.

Table 1. Criteria for assessment of the children's physical development
The study was aimed to assess the role of BIA of body composition in the diagnosis of the physical development disorders in children and adolescents.

\section{METHODS}

The cross-sectional cohort study of the prevalence of physical development disorders among the secondary school students of the general educational institutions in Samara based on the anthropometric and bioimpedance measurement data was carried out. The children were examined at their educational institutions from March to May 2021, with interruptions for spring vacation (March 22-28) and public holidays. A total of 431 children aged $12-16$ (the median age was 13 years 8 months) were examined: 230 boys (53.4\%) and 201 girls $(46.6 \%)$ of grades 5-9 of the general education schools.

Inclusion criteria: age 12-16 years, permanent residence in the territory of Samara region; compliance with the health status group I or II based on medical documentation; informed consent to the study participation submitted by parents (legal representatives). Exclusion criteria: age at the time of examination less than 11 years 6 months and one day or over 16 years 6 months and one day; chronic disorders; taking medications; prominent limb swelling; permanent residence outside of Samara region; no informed consent to participation or refusal of participation provided by parents (legal representatives).

Anthropometric indicators were measured in the following way: body height was measured with the MSK-233 stadiometer (Medstalkonstruktsiya; Russia) to within $5 \mathrm{~mm}$, and body weight was measured with the VEM-150-A1 medical scales (Massa-K; Russia) to within $50 \mathrm{~g}$. Body composition was defined by BIA using the ABC-01 internal environment analyzer (Medass; Russia) with the current probe frequency of $50 \mathrm{kHz}$ in accordance with the tetrapolar electrode scheme, involving electrode positioning on the wrist and ankle when the subject is in the supine position. Examination was not preceded by intense physical activity, eating or drinking. Room temperature was controlled in the rooms, where the examination was carried out.

The children's physical development was assessed based on the height to weight ratio in two different ways. The first method involved estimation of physical development with the use of the regional regression models, fitted with body weight as dependent variable and height, developed for Samara region [21]. The second method involved calculating the BMI for age Z-score (BAZ), and the resulting values were analyzed in accordance with the WHO standards [10] using the WHO AnthroPlus software (2009) (WHO; Switzerland) [22]. BMI was calculated as the child's weight $(\mathrm{kg})$ divided by the square of height (m2). Nutritional status was further assessed based on the data obtained by BIA of body composition, the body fat percentage (\%BF). The criteria for the estimation of the results are presented in Table 1.

The raw data were acquired and stored using the Microsoft Excel 2013 software (Microsoft; USA). Statistical processing

\begin{tabular}{|l|c|c|c|}
\hline \multirow{2}{*}{\multicolumn{1}{|c|}{ Indicator }} & \multicolumn{2}{c|}{ Assessment methods } \\
\cline { 2 - 4 } & BAZ, SDS [10] & Regression scores, $\sigma \mathrm{R}[22]$ & $<$ BIA, \%BF [23] \\
\hline Underweight & $<-2.0$ & $<-1.0$ & $<15^{\text {th }}$ percentile \\
\hline Normal development & from -2.0 to +1.0 & from +1.0 to +1.5 & from $25^{\text {th }}$ to $75^{\text {th }}$ percentile \\
\hline Overweight & from +1.0 to +2.0 & $\geq+1.5$ & $\geq 97^{\text {th }}$ percentile \\
\hline Obesity & $\geq+2.0$ & - & $27^{\text {th }}$ percentile \\
\hline
\end{tabular}


Table 2. Distribution of anthropometric indicators based on the BAZ indices in the studied sample of school students

\begin{tabular}{|l|c|c|c|c|c|}
\hline \multirow{2}{*}{ Studied group } & \multicolumn{5}{|c|}{ Z-score } \\
\cline { 2 - 6 } & $<-2.0$ & from -2.0 to -1.0 & from -1.0 to +1.0 & from +1.0 to +2.0 & $\geq+2.0$ \\
\hline Boys, abs. (\%) & $4(1.7)$ & $16(7)$ & $131(56.9)$ & $59(25.7)$ & $20(8.7)$ \\
\hline Girls, abs. (\%) & $3(1.5)$ & $32(15.9)$ & $124(61.7)$ & $23(11.5)$ & $19(9.4)$ \\
\hline All examined children, abs. (\%) & $7(1.6)$ & $48(11.1)$ & $255(59.1)$ & $82(19.1)$ & $39(9.1)$ \\
\hline
\end{tabular}

Note: normal values are highlighted

of the results was performed by the analysis of variance with the Statistica 13.1 software package (StatSoft Inc.; USA). Statistical significance of the differences was analyzed using the Pearson's $\chi^{2}$ test. The differences were considered significant when $p<0.05$.

\section{RESULTS}

Analysis of anthropometric traits in the studied group of children showed that the gradual increase in the height was observed both in boys and girls aged 12-16. In view of the fact that body weight is a dynamic parameter, depending primarily on the actual nutrition and the levels of physical activity, the analysis of dynamic changes in this trait has revealed no gradual increase with age and has reflected the correlation of the mean values with the percentage of children with the physical development disorders in the specified age group (Fig. 1).

Thus, when assessing physical development using the regional regression scores, it was found that more than $2 / 3$ of the examined school students were constituted by children with the normal pattern of physical development, while the percentage of children, who's body weight deviated from the reference values, was $30.44 \%$ in boys, and $38.36 \%$ in girls. However, the percentage of overweight children in boys and girls was the same (22.61\% and $23.43 \%)$, and the proportion of underweight children was higher in the group of girls $(14.93 \%)$, than in the group of boys $(7.83 \%, p<0.01)$.

Estimation of physical development based on the BAZ indices showed that in the studied group, children with normal body weight $(70.2 \%)$ prevailed among both boys (147/230, $63.9 \%)$, and girls (157/201, $77.6 \%)$. Low body weight was found in seven children (1.6\%) in the studied sample: four boys, and three girls. Excess body weight and obesity were revealed in less than one third of the surveyed children (in 19.1\%, and $9.1 \%$, respectively). Furthermore, there were no significant differences in the percentage of obese children among boys and girls $(p=0.207)$, while the proportion of overweight children was significantly higher in boys, than in girls $(p<0.01)$. Severe obesity (BAZ > +3.0) was found in three boys, and two girls (Table 2).

Comparison of the results, obtained by assessing physical development in accordance with the regional scores and the

Height $(\mathrm{cm})$

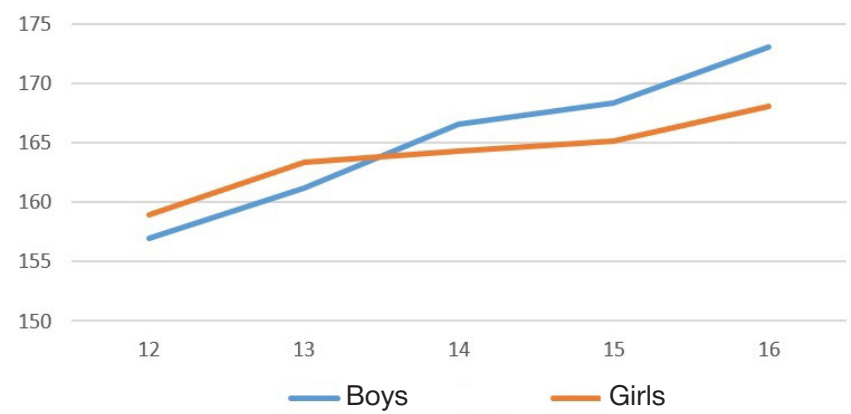

WHO standards (BAZ, Z-score), showed that Z-score revealed a significantly larger number of overweight and obese children among boys $(p<0.01)$. Regression scores revealed the insignificantly higher proportion of underweight boys ( $p=0.285$ ) and the significantly higher proportion of underweight girls $(p<0.01$ ) (Fig. 2).

Based on the BIA data, a half of children in the studied sample had the excessive fat content. Furthermore, excess body weight was found in $42.2 \%$ of boys and $40.8 \%$ of girls, and obesity was found in $6.5 \%$ and $7.5 \%$, respectively. Based on the \%BF, $6.1 \%$ of boys and $3.5 \%$ were underweight. Thus, BIA of body composition in children revealed a normal body fat percentage, appropriate for age, gender, and anthropometric data, only in a half of the surveyed children, which made up $45.2 \%$ in the group of boys, and $48.3 \%$ in the group of girls (Fig. 3).

When assessing body fat percentage in children with various levels of physical development based on the regression scores, the following was found: in the group with normal physical development, the proportion of children with normal body fat percentage was $40 \%$, while $44.7 \%$ of the surveyed individuals had excess fat content, and about $16.8 \%$ had low fat content. In the group of overweight children, high fat content values were found only in $72.7 \%$ of cases, which was indicative of the excess in other body weight characteristics (skeletal muscle mass, total body water, etc.) in $27.3 \%$ of children in this subgroup. The surveyed underweight children had a low body fat percentage in a half of cases (Fig. 4).

Studying the nutritional status in children with the relevant BAZ characteristics revealed $39.7 \%$ of surveyed individuals with normal body fat percentage; $21.9 \%$ of children had the low body fat percentage, and $38.2 \%$ of children had the excess body fat content. Among the surveyed children with BAZ between +1.0 and +2.0 Z-score (overweight), excess body fat percentage was revealed only in $56.1 \%$ of cases, $36.6 \%$ had a normal body fat content, and $7.3 \%$ had a low fat content. Obesity, defined based on BAZ, was confirmed by the \%BF values in $16.7 \%$ of cases, and low body weight was confirmed in $71.4 \%$ of cases of the appropriate subgroup of the sample (Fig . 4).

Thus, body weight aberrations, diagnosed based on the regional scores, were confirmed by the data of $\mathrm{BIA}$ in the

Body weight $(\mathrm{kg})$

Fig. 1. Age-dependent changes of anthropometric indicators of physical development in the studied sample of children

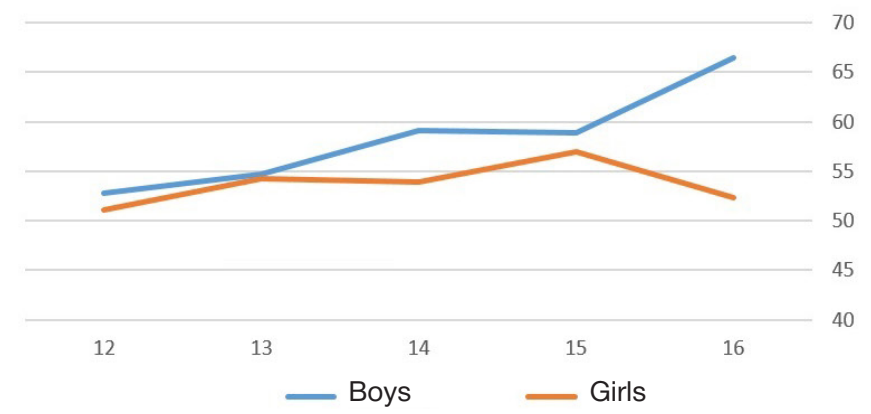
60 55 50 45

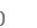




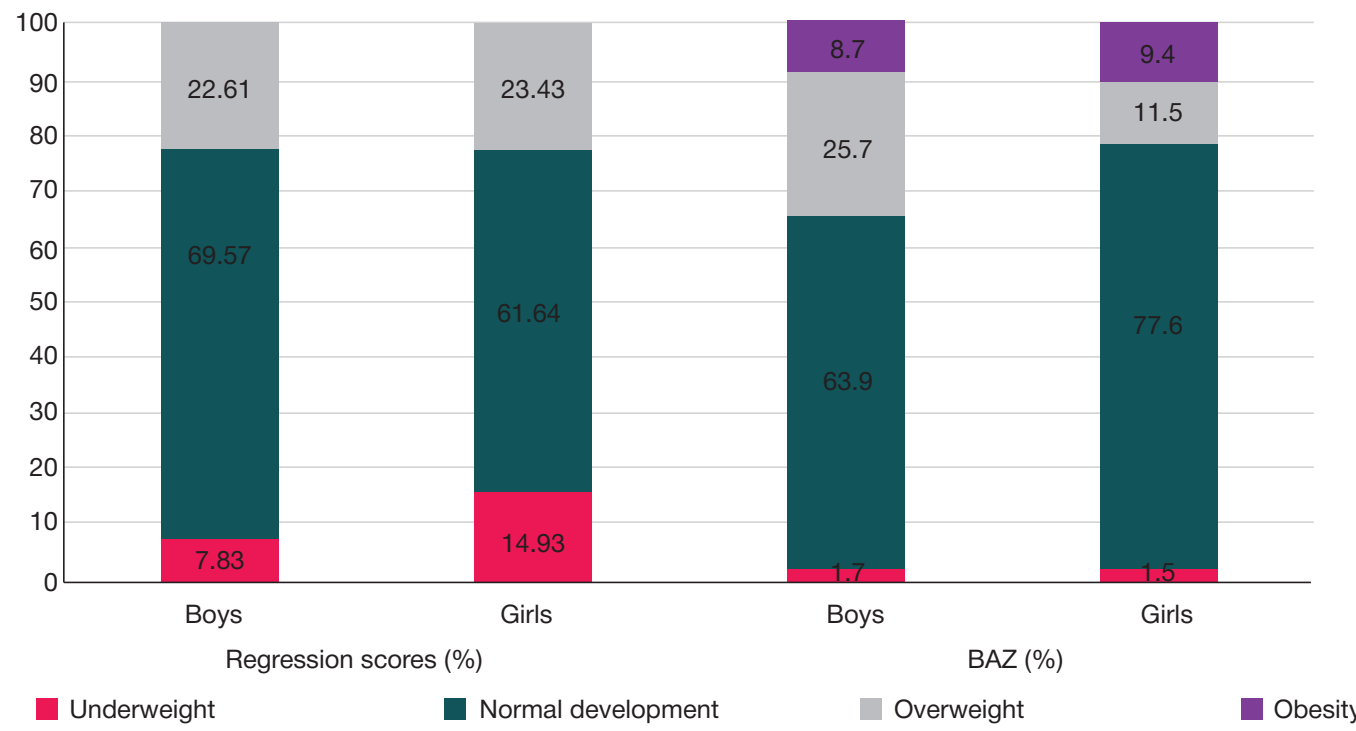

Fig. 2. Comparison of the results of the physical development assessment with the use of regression scores and BAZ indices in the groups of boys and girls, constituting the studied sample

significantly larger number of cases compared to the results of the assessment based on the BAZ indices (82/431, 19.7\% and $61 / 431,14.15 \%, p<0.05)$.

\section{DISCUSSION}

Our research, focused on studying the anthropometric indicators, involving the assessment of the school students aged 12-16 based on the regression scores, as well as on the calculated BAZ indices and \%BF values, revealed numerous overweight and obese children. When using the anthropometric diagnosis methods, the most pronounced fluctuations of body weight, including the upward (excess weight) and downward (underweight) bias, were identified by assessment, involving the use of regression scores. It is interesting to note that when using the body fat percentage values obtained by BIA as a criterion of excess body weight instead of the results of estimation based on the regional standards and BMI, the proportion of children, who could be diagnosed with overweight and obesity, changed significantly. No significant differences in the number of children with the normal pattern of physical development and children with body weight fluctuations between boys and girls were revealed based on the \%BF values. Furthermore, BIA made it possible to reveal a large proportion of overweight and obese children among the individuals with the normal pattern of physical development (based on the regression scores and BAZ indices).

The period of development between 12-16 years of age is a critical period, when the risk of obesity increases by several

Boys

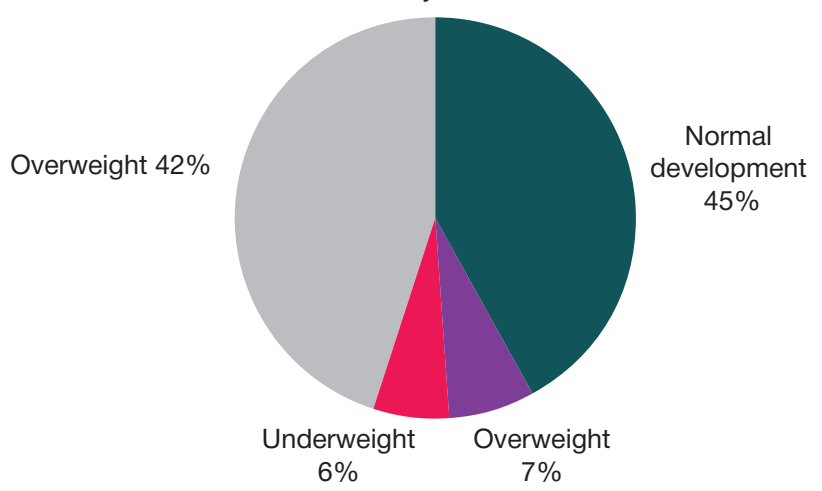

times [7, 24]. Moreover, $60 \%$ of children with excess body weight in adolescence would be obese in adulthood, with the more severe course of obesity, prominent body weight increase and high prevalence of comorbidities, in contrast to the adult-onset obesity $[7,25]$. That is why the early detection of premorbid conditions, aimed at adjusting the child's diet and daily routine, is a crucial step in preventive medicine in terms of obesity prevention. According to our study, the results of which are in line with the results, obtained by other researchers $[5,6,9]$, the anthropometric trait assessment results could be considered the most important criteria to be used in the routine check-ups, allowing one to refer the child to endocrinologist and nutritionist, and if necessary, for further treatment.

However, the findings showed that only $2 / 3$ of the school students, diagnosed with overweight with the use of anthropometric techniques, had the excess body fat content. Nevertheless, body fat percentage was normal in one third of children in the surveyed sample, and no therapeutic interventions were required. Therefore the method of BIA, allowing one to detect changes not only in the body fat mass, but also in all the fat-free (lean) body mass components, could be considered the diagnostic method, allowing the specialists to start treatment, such as diet therapy, and to dynamically monitor the efficiency of the interventions.

Close practical links between the BIA of body composition and the anthropometric assessment of young patients were frequently discussed in scientific literature $[19,26,27]$ with the emphasis on the high level of accountability of the biophysical method. Unfortunately, the diagnostic significance and the

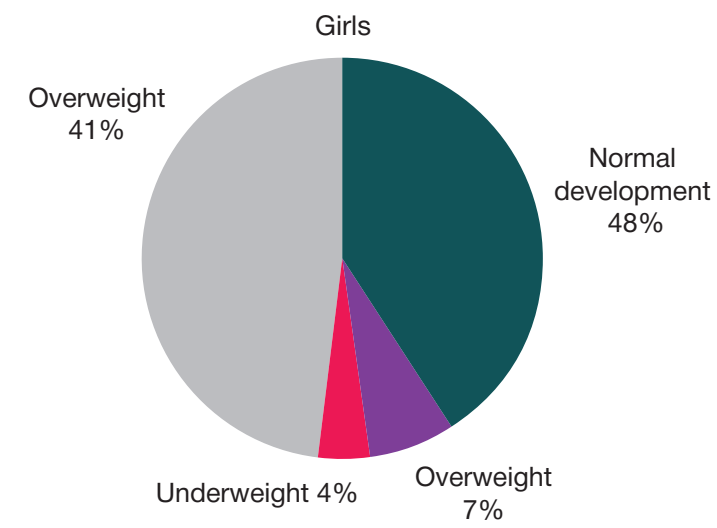

Fig. 3. Distribution of \%BF in the groups of boys and girls, constituting the studied sample 


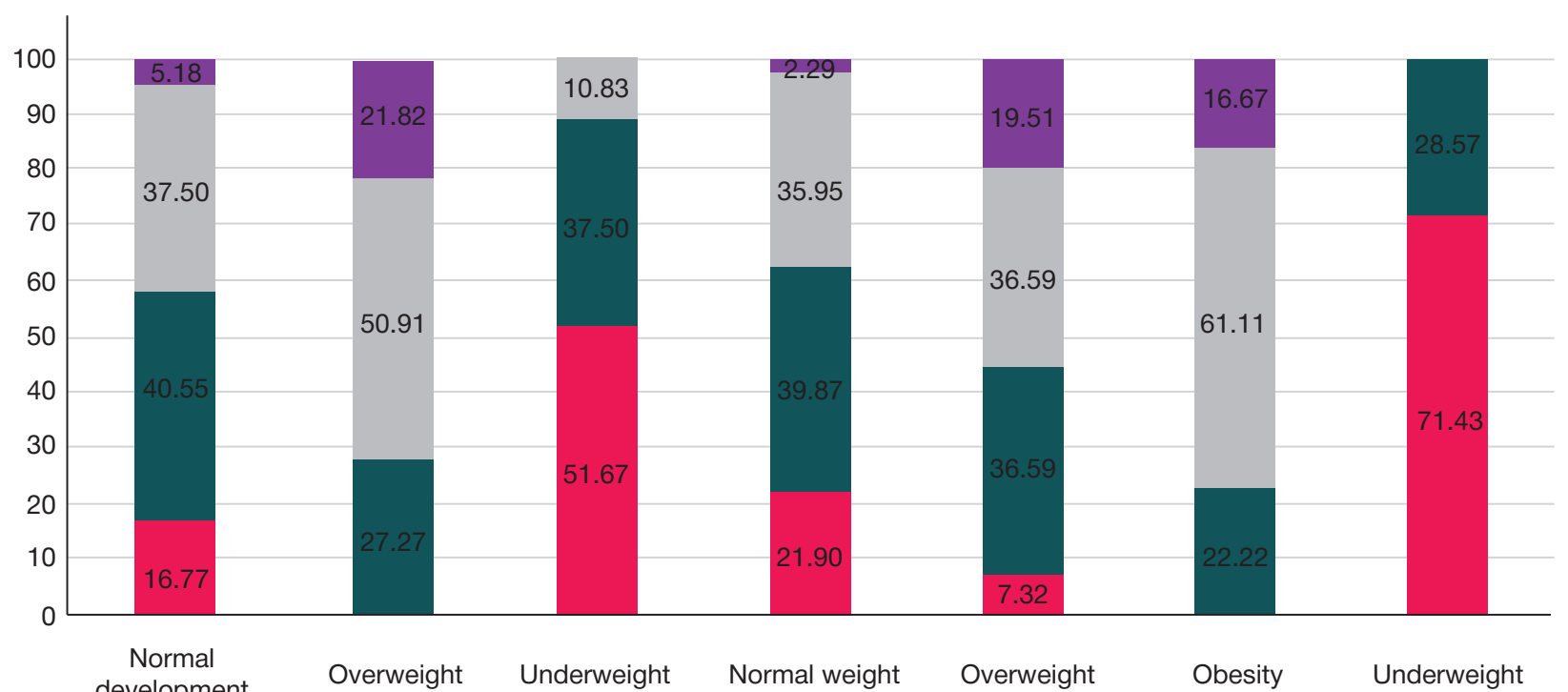

development Overweight Underweight Normal weight Overweight Obesity Underweight

Regression scores (\%)

$\mathrm{BAZ}(\%)$

Underweight

Normal weight

Overweight

Obesity

Fig. 4. Comparison of \%BF distributions depending on the levels of physical development when using regression scores and BAZ indices in the studied sample

criteria for the BIA results interpretation in combination with the anthropometric data have not been reflected in the federal guidelines on the diagnosis and treatment of obesity, which hampers the practical application of the method.

\section{CONCLUSIONS}

The study of anthropometric traits in the Samara school students aged 12-16 has revealed a significant proportion of children, having problems with physical development. The highest proportion of children with body weight fluctuations has been revealed by the assessment with the use of the regional age-based and gender-based regression scores, fitted with body weight as dependent variable and height. The analysis of body fat content in children with different levels of physical development has made it possible to identify the excess body fat percentage in children with the normal pattern of physical development (harmonious physical development). Thus, bioimpedance analysis of body composition in combination with the anthropometric data could be used as a reliable method for the diagnosis of the nutritional status disorders in children and adolescents.

\section{References}

1. Chernykh AM, Kremleva AS, Belova Al. 20-year monitoring of physical developmental characteristics in school-age children and adolescents living in Kursk. Russian Bulletin of Hygiene. 2021; (1): 42-6. DOI: 10.24075/rbh.2021.008.

2. Milushkina OYu, Skoblina NA, Markelova SV, Tatarinchik AA, Melikhova EP, Libina II, et al. The impact of electronic devices on the physical growth and development of modern youth and recommendations on their safe use. Bulletin of RSMU. 2019; (4): 83-9. DOI: 10.24075/brsmu.2019.046.

3. Novikova II, Gavrish SM, Romanenko SP, Sorokina AV, Serenko W, Kreimer MA. Comparative assessment of the informativity of indication methodsexcess body weight. Sanitary doctor. 2021; (4) 67-8. DOI: 10.33920/med-08-2104-07. Russian.

4. Shestera AA, Khmelnitskaya EA, Kiku PF, Perelomova OV, Kaerova EV, Sabirova KM. Physical development and functional possibilities of youth of Vladivostok. Public Health and Life Environment. 2019; (11): 61-5. DOI: https://doi.org/10.35627/2219-5238/2019-32011-61-65. Russian.

5. Latyshevskaya NI, Yatsyshen W, Davidenko LA, Yatsyshen TL. Dynamics of anthropometric indices of children and adolescents in the city of Volgograd (1976-2016). Hygiene and Sanitation. 2018; 97(9): 844-7. DOI: http://dx.doi.org/10.18821/0016-99002018-97-9-844-847. Russian.

6. Tsukareva EA, Avchinnikov AV, Alimova IL. Assessment of physical development and diet of primary school children in Smolensk. Voprosy pitaniia. 2019; 88 (4): 34-40. DOI: 10.24411/0042-8833-
2019-10039. Russian.

7. Gavryushin MYu, Sazonova OV, Milushkina OYu, Skoblina NA, Borodina LM, Gorbachev DO. Actual problems of assessment and correction of the nutritional status of modern children. In: Gerasimenko NF, Glybochko PV, Esaulenko IE, Popov VI, Starodubov VI, Tutelyan VA, editors. Youth health: new challenges and prospects: a monograph in 5 vols. Vol. 3: Technologies for reducing health risks. Prevention and medical examination. Healthy eating. Moscow; 2019. p. 250-70. Russian.

8. Girsh YaV, Gerasimchik OA. The role and place of bioimpedance analysis assessment of body composition of children and adolescents with different body mass. Bulletin of Siberian Medicine. 2018; 17 (2): 121-32. DOI: https://doi.org/10.20538/1682-03632018-2-121-132. Russian.

9. Namazova-Baranova LS, Yeletskaya KA, Kaytukova EV, Makarova SG. Evaluation of the physical development of children of secondary school age: an analysis of the results of a crosssectional study. Pediatric pharmacology. 2018; 15 (4): 333-42. DOI: https://doi.org/10.15690/pf.v15i4.1948. Russian.

10. De Onis M, Onyango AW, Borghi E, et al. Development of a WHO growth reference for school-aged children and adolescents. Bulletin of the World Health Organization. 2007; (85): 660-7. DOI: 10.2471/blt.07.043497.

11. Borodkina DA, Gruzdeva OV, Kvitkova LV, Barbarash OL. Body fat distribution: the answer to the apparent paradox of obesity 
in cardiology? Obesity and metabolism. 2017; 14 (2): 3-8. DOI: 10.14341/omet201723-8. Russian.

12. Demyanenko IA, Tkach AV. Functional morphology of adipose tissue and its role in the formation of metabolic syndrome. Crimea Journal of Experimental and Clinical Medicine. 2021; 11 (1): 5160. DOI: 10.37279/2224-6444-2021-11-1-51-60. Russian.

13. Galimov OV, Khanov VO, Ziangirov RA, Galimova ES, Minigalin DM, Galimov DO. Stomach wall changes after gastroplication in patients with morbid obesity. Bulletin of RSMU. 2020; (4): 67-71. DOI: 10.24075/brsmu.2020.041.

14. Grossman DC, Bibbins-Domingo K, Curry SJ, et al. Screening for obesity in children and adolescents us preventive services task force recommendation statement. Journal of the American Medical Association. 2017; 317 (23): 2417-26. DOI: 10.1001/ jama.2017.6803.

15. Gritsinskaya VL. Evaluation of physical development of schoolage boys in Saint Petersburg with the use of the anthropometric calculator of WHO. Public Health and Life Environment. 2018; (2): 16-19. Russian.

16. Almeida $Y$, Costa Maia C, Barros N, Moreno L, Carioca A, Loureiro A. Is bioelectrical impedance vector analysis a good indicator of nutritional status in children and adolescents? Public Health Nutrition. 2021; 24 (14): 4408-16. DOI:10.1017/ S1368980021002226.

17. Karanikas I, Karayiannis D, Karachaliou A, Papanikolaou A, Chourdakis M, Kakavas S. Body composition parameters and functional status test in predicting future acute exacerbation risk among hospitalized patients with chronic obstructive pulmonary disease. Clinical Nutrition. 2021; 40 (11): 5605-14. DOI: 10.1016/j. clnu.2021.09.035

18. Canfell OJ, Littlewood R, Wright ORL,Walker JL. Clinical relevance and validity of tools to predict infant, childhood and adulthood obesity: A systematic review. Public Health Nutrition. 2018; 21 (17): 3135-47. DOI: 10.1017/S1368980018001684.

19. Perevoshchikova NK, Seliverstov IA, Drakina SA, Chernykh NS.
Bioelectrical impedance analysis in clinical practice. Mother and Baby in Kuzbass. 2021; 3 (86): 11-20. DOI: 10.24412/26867338-2021-3-11-20. Russian.

20. Smirnova GA, Andriyanov Al, Kravchenko EV, Konovalova IA. The selection of optimal methods for determining the perfect body weight for the assessment of the nutritional status. Problems of Nutrition. 2019; 88 (5): 39-44. DOI: 10.24411/0042-8833-201910052. Russian.

21. Vdovenko SA, Sazonova OV, Ponomarev VA, Mazur LI, Gavryushin MYu, Borodina LM. Ocenochnye tablicy fizicheskogo razvitiya detej i podrostkov shkol'nogo voz-rasta Samarskoj oblasti. Metodicheskie rekomendacii. Samara, 2018; 46 p. Russian.

22. Growth reference 5-19 years. Application tools. WHO AnthroPlus software [Internet]. [cited 2021 Aug 12]. Available from: https://www.who.int/toolkits/growth-reference-data-for-5to19years/application-tools.

23. Rudnev SG, Soboleva NP, Sterlikov SA, Nikolaev DV, Starunova $\mathrm{OA}$, Chernyh SP et al. Bioimpedansnoe issledovanie sostava tela naselenija Rossii. M.: RIO CNIIOIZ MZ RF, 2014; 493 p. Russian.

24. Vasyukova OV. Obesity in children and adolescents: diagnosis criteria. Obesity and metabolism. 2019; 16 (1): 70-3. DOI: https:// doi.org/10.14341/omet10170. Russian.

25. Dadaeva VA, Aleksandrov AA, Drapkina OM. Prevention of obesity in children and adolescents. Profilakticheskaya Meditsina. 2020; 23 (1): 142-7. DOI: https://doi.org/10.17116/ profmed202023011142. Russian.

26. Lir DN, Perevalov AYa. The effectiveness of the improvement of health in the schoolchildren staying in a country summer camp. Voprosy kurortologii, fizioterapii, i lechebnoi fizicheskoi kultury. 2017; 94 (4): 48-53. DOl: https://doi.org/10.17116/kurort201794448-53. Russian.

27. Gavryushin MYu, Markelova SV, Skoblina NA, Milushkina OYu, Sazonova OV. Evaluation of the effectiveness of children's health improvement in camps: actual problems and its solutions. Problems of balneology, physiotherapy, and exercise therapy. 2021; 98 (4): 32-41. DOI: https://doi.org/10.17116/kurort20219804132. Russian.

\section{Литература}

1. Черных А. М., Кремлева А. С., Белова А. И. Мониторинг физического развития школьников города Курска в динамике двадцати лет наблюдения. Российский вестник гигиены. 2021; (1): 42-6. DOI: 10.24075/rbh.2021.008.

2. Милушкина О. Ю., Скоблина Н. А., Маркелова С. В., Татаринчик А. А., Мелихова Е. П., Либина И. И. и др. Влияние электронных устройств на физическое развитие современной молодежи и рекомендации по регламенту их использования. Вестник РГМУ. 2019; (4): 87-94. DOI: 10.24075/vrgmu.2019.046.

3. Новикова И. И., Гавриш С. М., Романенко С. П., Сорокина А. В., Серенко В. В., Креймер М. А. Сравнительная оценка информативности методов индикации избыточной массь тела. Санитарный врач. 2021; (4) 67-8.

4. Шестёра А. А., Хмельницкая ЕА., Кику П. Ф., Переломова О. В., Каерова Е. В., Сабирова К. М. Физическое развитие и функциональные возможности молодежи города Владивостока. Здоровье населения и среда обитания. 2019; 11 (320): 61-5. DOI: http://doi.org/10.35627/2219$5238 / 2019-320-11-61-65$

5. Латышевская Н. И., Яцышен В. В., Давыденко Л. А., Яцышена Т. Л. Динамика физического развития детей и подростков города Волгограда в 1976-2016 гг. Гигиена и санитария. 2018, 9 7(9): 844-7. DOI: http://dx.doi.org/10.18821/0016-9900-201897-9-844-847.

6. Цукарева Е. А., Авчинников А. В., Алимова И. Л. Оценка физического развития и режима питания детей младшего школьного возраста, проживающих в Смоленске. Вопросы питания. 2019; 88 (4): 34-40. DOI: 10.24411/0042-8833-201910039.

7. Гаврюшин М. Ю., Сазонова О. В., Милушкина О. Ю., Скоблина Н. А., Бородина Л. М., Горбачев Д. О. Актуальные проблемь оценки и коррекции пищевого статуса современных детей.

В книге: Герасименко Н. Ф., Глыбочко П. В., Есауленко И. Э., Попов В. И., Стародубов В. И., Тутельян В. А., редакторы. Здоровье молодежи: новые вызовы и перспективы: монография в 5 т. Т. 3: Технологии снижения рисков здоровью. Профилактика и диспансеризация. Здоровое питание. М., 2019; с. 250-70.

8. Гирш Я. В., Герасимчик О. А. Роль и место биоимпедансного анализа в оценке состава тела детей и подростков с различной массой тела. Бюллетень сибирской медицины. 2018; 17 (2): 121-32. DOI: 10.20538/1682-0363-2018-2-121-132.

9. Намазова-Баранова Л. С., Елецкая К. А., Кайтукова Е. В., Макарова С. Г. Оценка физического развития детей среднего и старшего школьного возраста: анализ результатов одномоментного исследования. Педиатрическая фармакология. 2018; 15 (4): 333-42. DOI: 10.15690/pf.v15i4.1948.

10. De Onis M, Onyango AW, Borghi E, et al. Development of a WHO growth reference for school-aged children and adolescents. Bulletin of the World Health Organization. 2007; (85): 660-7. DOI: 10.2471/blt.07.043497.

11. Бородкина Д. А., Груздева О. В., Квиткова Л. В., Барбараш О. Л. Распределение жировых отложений: разгадка кажущегося парадокса ожирения в кардиологии? Ожирение и метаболизм. 2017; 14 (2): 3-8. DOI: 10.14341/omet201723-8.

12. Демьяненко И. А., Ткач А. В. Функциональная морфология жировой ткани и ее роль в формировании метаболического синдрома. Крымский журнал экспериментальной и клинической медицины. 2021; 11 (1): 51-60. DOI: 10.37279/2224-64442021-11-1-51-60.

13. Галимов О. В., Ханов В. О., Зиангиров Р. А., Галимова Е. С., Минигалин Д. М., Галимов Д. О. Изменения в стенке желудка после гастропликации у пациентов с морбидным ожирением. Вестник РГМУ. 2020; (4): 70-5. DOI: 10.24075/vrgmu.2020.041.

14. Grossman DC, Bibbins-Domingo K, Curry SJ, et al. Screening 
for obesity in children and adolescents us preventive services task force recommendation statement. Journal of the American Medical Association. 2017; 317 (23): 2417-26. DOI: 10.1001/ jama.2017.6803.

15. Грицинская В. Л. Оценка физического развития мальчиков школьного возраста г. Санкт-Петербурга с использованием антропометрического калькулятора ВОЗ. Здоровье населения и среда обитания. 2018; (2): 16-19.

16. Almeida Y, Costa Maia C, Barros N, Moreno L, Carioca A, Loureiro A. Is bioelectrical impedance vector analysis a good indicator of nutritional status in children and adolescents? Public Health Nutrition. 2021; 24 (14): 4408-16. DOI:10.1017/ S1368980021002226.

17. Karanikas I, Karayiannis D, Karachaliou A, Papanikolaou A, Chourdakis M, Kakavas S. Body composition parameters and functional status test in predicting future acute exacerbation risk among hospitalized patients with chronic obstructive pulmonary disease. Clinical Nutrition. 2021; 40 (11): 5605-14. DOI: 10.1016/j. clnu.2021.09.035.

18. Canfell OJ, Littlewood R, Wright ORL,Walker JL. Clinical relevance and validity of tools to predict infant, childhood and adulthood obesity: A systematic review. Public Health Nutrition. 2018; 21 (17): 3135-47. DOI: 10.1017/S1368980018001684.

19. Перевощикова Н. К., Селиверстов И. А., Дракина С. А., Черных Н. С. Биоимпедансный анализ в клинической практике. Мать и Дитя в Кузбассе. 2021; 3 (86): 11-20. DOI: 10.24412/2686-7338-2021-3-11-20.

20. Смирнова Г. А., Андриянов А. И., Кравченко Е. В., Коновалова И. А. Выбор оптимальных методик определения идеальной массы тела для оценки состояния питания. Вопросы питания. 2019; 88 (5): 39-44. DOI: 10.24411/0042-8833-2019-10052.
21. Вдовенко С. А., Сазонова О. В., Пономарев В. А., Мазур Л. И., Гаврюшин М. Ю., Бородина Л. М. Оценочные таблицы физического развития детей и подростков школьного возраста Самарской области. Методические рекомендации. Самара, 2018; 46 c.

22. Growth reference 5-19 years. Application tools. WHO AnthroPlus software [Internet]. [cited 2021 Aug 12]. Available from: https://www.who.int/toolkits/growth-reference-data-for-5to19years/application-tools.

23. Руднев С. Г., Соболева Н. П., Стерликов С. А., Николаев Д. В., Старунова О. А., Черных С. П. и др. Биоимпедансное исследование состава тела населения России. М.: РИО ЦНИИОИЗ МЗ РФ, 2014; 493 с.

24. Васюкова О. В. Ожирение у детей и подростков: критерии диагноза. Ожирение и метаболизм. 2019; 16 (1): 70-3. DOI: https://doi.org/10.14341/omet10170.

25. Дадаева В. А., Александров А. А., Драпкина О. М. Профилактика ожирения у детей и подростков. Профилактическая медицина. 2020; 23 (1): 142-7. DOI: https://doi.org/10.17116/profmed202023011142.

26. Лир Д. Н., Перевалов А. Я. Эффективность оздоровления школьников за время пребывания в летнем загородном учреждении отдыха. Вопросы курортологии, физиотерапии и лечебной физической культуры. 2017; 94 (4): 48-53. DOI: https://doi.org/10.17116/kurort201794448-53.

27. Гаврюшин М. Ю., Маркелова С. В., Скоблина Н. А., Милушкина О. Ю., Сазонова О. В. Оценка эффективности оздоровления детей в лагерях: современные проблемы и пути решения. Вопросы курортологии, физиотерапии и лечебной физической культуры. 2021; 98 (4): 32-41. DOI: https://doi. org/10.17116/kurort20219804132. 